\title{
Phase Transformation of Iron Oxide Nanoparticles from Hematite to Maghemite in Presence of Polyethylene Glycol: Application as Corrosion Resistant Nanoparticle Paints
}

\author{
Pavani Katikaneani, ${ }^{1}$ Ajay Kumar Vaddepally, ${ }^{2}$ Narender Reddy Tippana, ${ }^{2}$ \\ Ramu Banavath, ${ }^{2}$ and Srivani Kommu ${ }^{2}$ \\ ${ }^{1}$ Department of Chemistry, Rajiv Gandhi University of Knowledge Technologies-Basar, Telangana 504107, India \\ ${ }^{2}$ Department of Metallurgical and Materials Engineering, Rajiv Gandhi University of Knowledge Technologies-Basar, \\ Telangana 504107, India
}

Correspondence should be addressed to Pavani Katikaneani; kpavani@rgukt.ac.in

Received 27 June 2016; Revised 23 July 2016; Accepted 25 July 2016

Academic Editor: Zhengjun Zhang

Copyright ( 2016 Pavani Katikaneani et al. This is an open access article distributed under the Creative Commons Attribution License, which permits unrestricted use, distribution, and reproduction in any medium, provided the original work is properly cited.

\begin{abstract}
This work proposes a simple method for the efficient and rapid synthesis of hematite $\left(\alpha-\mathrm{Fe}_{2} \mathrm{O}_{3}\right)$ nanostructures based on simple heating method under ambient conditions. Polyethylene glycol (PEG) is employed as a structure directing agent in driving the morphology and phase transformation. Typically, $\mathrm{Fe}_{2} \mathrm{O}_{3}$ nanoparticles of size below $50 \mathrm{~nm}$ were synthesized at temperature around $500^{\circ} \mathrm{C}$. The morphology and mechanism of formation of the nanocapsules and then aggregation of nanocapsules to form larger size nanoclusters were studied by scanning electron microscopy and energy dispersive X-ray spectroscopy. Interestingly, this work demonstrates the structural phase transformation of hematite $\left(\alpha-\mathrm{Fe}_{2} \mathrm{O}_{3}\right)$ to maghemite $\left(\gamma-\mathrm{Fe}_{2} \mathrm{O}_{3}\right)$ upon addition of different amounts of PEG (say $0.066 \mathrm{M}, 0.133 \mathrm{M}$, and $0.2 \mathrm{M}$ ) and then heat treating at $500^{\circ} \mathrm{C}$. The prepared powders were used in nanoparticle paint preparation and applied as corrosion resistant coatings on iron samples. Polarization studies performed on the paint coatings made out of all the prepared samples showed size-dependent corrosion resistance. As the particle size decreases, the surface area increases and so the corrosion resistance also increases.
\end{abstract}

\section{Introduction}

From the last few decades, transition metal oxide nanoparticles have attracted tremendous interest due to their promising applications as electrode materials for rechargeable solidstate batteries [1,2], as efficient catalysts for fuel-cell reactions $[3,4]$, and as nanoscale magnetic models for understanding nanomagnetism $[5,6]$. Amongst these, iron oxide nanoparticles have received much attention due to their massive applications in the fields of information storage disks, ferrofluids, pigments, and medical applications like targeted drug delivery and cancer diagnoses [7-9]. Iron (III) oxide is an inorganic compound with the formula $\mathrm{Fe}_{2} \mathrm{O}_{3}$ and it is of one of the three main oxides of iron; the other two are rarely available iron (II) oxide $(\mathrm{FeO})$ and naturally occurring iron (II, III) oxide $\left(\mathrm{Fe}_{3} \mathrm{O}_{4}\right)$. In steel industry, hematite is the main source of the iron for the production of steel and it is paramagnetic, readily attacked by acids, and reddish brown in colour. As hematite is the most stable and ntype semiconductor under ambient conditions, it is widely used as catalysts, gas sensors, and pigments due to its high resistance to corrosion and low cost. It can also be used as a starting material for the synthesis of maghemite $\left(\gamma-\mathrm{Fe}_{2} \mathrm{O}_{3}\right)$ and magnetite $\left(\mathrm{Fe}_{3} \mathrm{O}_{4}\right)$, which have been intensively pursued for technological applications in the last few decades [10]. However, hematite is also interesting material as it has a band gap of $2.3 \mathrm{eV}$; the conduction band (CB) is composed of empty d-orbitals of $\mathrm{Fe}^{3+}$ and the valence band (VB) consists of fully occupied 3D crystal field orbitals of $\mathrm{Fe}^{3+}$ with some admixture from the $\mathrm{O} 2 \mathrm{p}$ nonbonding orbitals [11]. Several methods to synthesize iron oxide nanoparticles such as mechanochemical $[12,13]$, wire electrical explosion [14], 
TABLE 1: Experimental details.

\begin{tabular}{lccc}
\hline Sample code & Precursor $0.589 \mathrm{M}\left[\mathrm{Fe}\left(\mathrm{NO}_{3}\right)_{3} \cdot 9 \mathrm{H}_{2} \mathrm{O}\right]$ solution $(\mathrm{mL})$ & Amount of PEG in g & $\begin{array}{c}\text { Molar ratio } \\
\text { (precursor: PEG) }\end{array}$ \\
\hline $\mathrm{Fe}_{2} \mathrm{O}_{3}-0 \mathrm{PEG}$ & 10 & 0 & - \\
$\mathrm{Fe}_{2} \mathrm{O}_{3}-4 \mathrm{PEG}$ & 10 & $4(0.066 \mathrm{M})$ & $8.9: 1$ \\
$\mathrm{Fe}_{2} \mathrm{O}_{3}-8 \mathrm{PEG}$ & 10 & $8(0.133 \mathrm{M})$ & $4.4: 1$ \\
$\mathrm{Fe}_{2} \mathrm{O}_{3}-12 \mathrm{PEG}$ & 10 & $12(0.2 \mathrm{M})$ & $2.9: 1$ \\
\hline
\end{tabular}

and electrochemical $[15,16]$ methods have been reported. On the other hand, the method employed in the present work is simple heating method in presence of PEG. Iron nitrate nonahydrate was used as a precursor to formulate $\mathrm{Fe}_{2} \mathrm{O}_{3}$ nanostructures involving simple heating process with varying amounts of PEG. The prepared samples were characterized by X-ray diffraction, field emission scanning electron microscopy, and energy dispersive X-ray spectroscopy (EDX). Interestingly, powder XRD was found to show phase transformation from $\alpha-\mathrm{Fe}_{2} \mathrm{O}_{3}$ to $\gamma-\mathrm{Fe}_{2} \mathrm{O}_{3}$ with the increase in PEG concentration. This type of transformation is commonly observed with the effect of temperature $[17,18]$. The prepared nanoparticles were used in paint preparation and were found to show excellent corrosion resistance as coatings.

\section{Experimental Method}

2.1. Synthesis. Iron oxide nanoparticles $\left(\mathrm{Fe}_{2} \mathrm{O}_{3}\right)$ are prepared by simple heating method. This process involves preparation of $0.589 \mathrm{M}$ solution of ferric nitrate nonahydrate salt precursor by dissolving $10 \mathrm{~g}$ of $\mathrm{Fe}\left(\mathrm{NO}_{3}\right)_{3} \cdot 9 \mathrm{H}_{2} \mathrm{O}$ in $42 \mathrm{~mL}$ water to precipitate the oxohydrate at higher temperatures $\left(\sim 70^{\circ} \mathrm{C}\right)$. To each $10 \mathrm{~mL}$ of prepared salt precursor solution, various amount of PEG (0 M, 0.066 M, 0.133 M, 0.2 M) (as shown in Table 1 ) is added and stirred for one hour at higher temperatures $\left(\sim 100^{\circ} \mathrm{C}\right)$ till the homogeneous viscous solution is formed. These viscous materials were heat treated at $500^{\circ} \mathrm{C}$ for 1 hour to obtain different iron oxide nanopowders.

2.2. Characterization. The crystal structure of the synthesized particles was determined by powder X-ray diffractometer (D8 Discover, Bruker AXS Co., Ltd., Germany) with $\mathrm{Cu}-\mathrm{K} \alpha$ radiation, $\lambda=1.54056 \AA$. The particle size and morphology were derived from field emission gun scanning electron microscope (Carl Zeiss Co. Ltd., Germany) and the elemental composition was obtained from energy dispersive X-ray spectroscopy attached to FESEM (EDX INCA, Oxford Instruments).

\subsection{Corrosion Study}

2.3.1. Paint Preparation. Paint preparation involves (i) pigment preparation, (ii) binder preparation, and (iii) pigment binder grinding. Pigment preparation is carried out by taking prepared iron oxide nanoparticles of $1 \mathrm{~g}$ each $\left(\mathrm{Fe}_{2} \mathrm{O}_{3}-0\right.$ PEG, $\mathrm{Fe}_{2} \mathrm{O}_{3}-4$ PEG, $\mathrm{Fe}_{2} \mathrm{O}_{3}-8$ PEG, and $\mathrm{Fe}_{2} \mathrm{O}_{3}-12$ PEG) onto a glass slab and made into paste using linseed oil. The iron oxide particles were taken onto a glass slab and then a crater is made in the middle of the powder, into the crater $1 \mathrm{~mL}$ of linseed oil is poured, and the mixture was mixed thoroughly with pallet knife. Along with this, binder is prepared by the addition of $2 \%$ of bee wax in the linseed oil. For this purpose, $0.4 \mathrm{~g}$ of bee wax is added to $19.6 \mathrm{~mL}$ of linseed oil and the mixture was heated at $60^{\circ} \mathrm{C}$ along with magnetic stirring, until all the wax gets dissolved in linseed oil and the colour of mixture turns out to be yellowish. This is cooled to room temperature and can be used as binder. Once the binder cools to room temperature, the pigment is taken onto glass slab; few drops of binder are added and ground well using a miller till the pigment gets mixed up with binder and feels like paint. The prepared paint is stored in plastic containers and was coated on thin sheets of iron on one side and tested for polarization curves.

2.3.2. Potentiodynamic Polarization Curve. A characteristic three-electrode electrochemical corrosion cell was used in all the experiments. As a reference, a saturated calomel electrode (SCE) was used. All measured potentials were referred to this electrode. A platinum foil was used as the counter electrode. Then (i) parent iron sample (blank uncoated sample) and iron samples coated with paints prepared out of (ii) $\mathrm{Fe}_{2} \mathrm{O}_{3}-0$ PEG, (iii) $\mathrm{Fe}_{2} \mathrm{O}_{3}-4$ PEG, (iv) $\mathrm{Fe}_{2} \mathrm{O}_{3}-8$ PEG, (v) $\mathrm{Fe}_{2} \mathrm{O}_{3}-12$ PEG, and (vi) microsized $\mathrm{Fe}_{2} \mathrm{O}_{3}$ powder were used as working electrodes. A potentiostat (IEC 61326, Ivium Technologies, Netherlands), controlled by a personal computer, equipped with a GPIB card and the commercial software, was employed to attain the potentiodynamic polarization curves. Before every experiment, the open circuit potential (OCP) was recorded for at least 30 minutes. Polarization curves were obtained potentiodinamically; the linear potential sweep was performed at a $\pm 248 \mathrm{mV}$ potential window around the measured OCP, from the cathodic to the anodic side, at scan rates of 0.1 and $1 \mathrm{mV} \mathrm{s}^{-1}$.

\section{Results and Discussion}

3.1. Powder XRD. The powder X-ray diffraction (XRD) was performed to identify the phase composition of nanoparticles. Iron oxides have many phases such as magnetite $\left(\mathrm{Fe}_{3} \mathrm{O}_{4}\right)$ and maghemite $\left(\gamma-\mathrm{Fe}_{2} \mathrm{O}_{3}\right)$ with cubic crystal structure and hematite $\left(\alpha-\mathrm{Fe}_{2} \mathrm{O}_{3}\right)$ with rhombohedral crystal structure. The magnetite and maghemite have black and light brown colours, respectively [14], due to the similar crystal structure and close lattice parameters $(a=8.396 \AA$ for magnetite and 


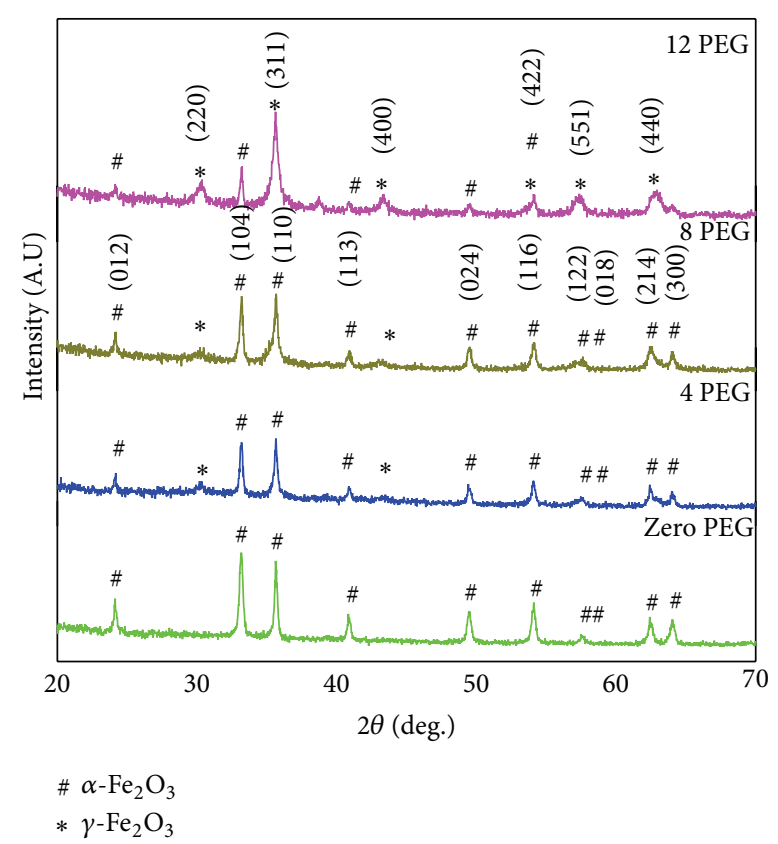

FIgURE 1: Powder XRD patterns of $\mathrm{Fe}_{2} \mathrm{O}_{3}$ nanoparticles at different concentrations of PEG.

$a=8.351 \AA$ for maghemite); they are similar in their X-ray diffraction patterns [19]. $\mathrm{Fe}^{3+}$ ions in $\alpha-\mathrm{Fe}_{2} \mathrm{O}_{3}$ occupy twothirds of the octahedral sites that are confined by the virtually ideal hexagonal close-packed $\mathrm{O}$ lattice. The structure of $\gamma$ $\mathrm{Fe}_{2} \mathrm{O}_{3}$ is cubic; each unit of maghemite contains $32 \mathrm{O}^{2-}$ ions, $21.3 \mathrm{Fe}^{3+}$ ions, and 2.3 vacancies. Oxygen anions give rise to a cubic close-packed arrangement, while ferric ions are distributed over tetrahedral sites (eight Fe ions per unit cell) and octahedral sites (the remaining Fe ions and vacancies).

Figure 1 shows powder XRD patterns of all synthesized iron oxide nanoparticles. As can be observed, the iron oxide prepared in the absence of PEG $\left(\mathrm{Fe}_{2} \mathrm{O}_{3}-0\right.$ PEG) and after heat treatment at $500^{\circ} \mathrm{C}$ showed pure hematite $\alpha$ $\mathrm{Fe}_{2} \mathrm{O}_{3}$ phase, matching exactly with PDF-01-077-9926. The main peak of hematite at $33.15^{\circ}$ is clearly observed. Other peaks at $24.1^{\circ}, 35.6^{\circ}, 40.8^{\circ}, 49.4^{\circ}, 54.1^{\circ}, 57.4^{\circ}$ (doublet), $62.4^{\circ}$, and $63.9^{\circ}$ are found and indexed. However, the iron oxide synthesized in presence of PEG and heat treated at same temperature starts showing a phase transformation as observed from Figure 1; the main peak of hematite at $33.15^{\circ}$ decreases in intensity and new peaks corresponding to maghemite $\left(\gamma-\mathrm{Fe}_{2} \mathrm{O}_{3}\right)$ appear at $30^{\circ}$ and nearly $43.5^{\circ}$. Interestingly, the addition of $12 \mathrm{~g}(0.2 \mathrm{M})$ of PEG shows major phase of maghemite $\left(\gamma-\mathrm{Fe}_{2} \mathrm{O}_{3}\right)$ which can be well indexed and matched with PDF-00-039-1346 along with small amount of hematite $\alpha-\mathrm{Fe}_{2} \mathrm{O}_{3}$ still remaining. The percentages calculated from Diffrac Eva software show $72.91 \%$ of maghemite $(\gamma$ $\left.\mathrm{Fe}_{2} \mathrm{O}_{3}\right)$ and $27.09 \%$ of hematite $\left(\alpha-\mathrm{Fe}_{2} \mathrm{O}_{3}\right)$ (refer to supplementary information in Supplementary Material available online at http://dx.doi.org/10.1155/2016/1328463). Phase transformation as a function of temperature is a common phenomenon $[17,18]$, but interestingly in the present work the phase transformation from hematite to maghemite phase is occurring on treatment with various amounts of PEG $(0 \mathrm{M}$, $0.066 \mathrm{M}, 0.133 \mathrm{M}$, and $0.2 \mathrm{M}$ ). The reason may be attributed to the fact that the phase transformation in iron oxides is often controlled by size-dependent thermodynamic relationships between initial and final product phases. The new phase is not thermodynamically favored until crystallites of the initial phase have assembled to certain critical size. These formed secondary structures underwent phase transformation, in which a new mineral phase begins forming at the interface between two surfaces of the initial phase [20].

3.2. SEM and EDX. The purpose of study was to measure the size and morphology of the prepared nanoparticles from SEM measurements. Figure 2 shows the SEM images of samples which were prepared in presence of various amounts of PEG. Interestingly, it was observed that the particles prepared in the absence of PEG showed irregular morphology including spherical particles whose size was larger when compared to other samples, although existing in the nanorange. When prepared with $4 \mathrm{~g}(0.066 \mathrm{M})$ and $8 \mathrm{~g}(0.133 \mathrm{M})$ of PEG, the morphology of particles is capsule shaped and is uniform in size and shape. With $4 \mathrm{~g}(0.066 \mathrm{M})$ of PEG, nanocapsules of length of $62 \mathrm{~nm}$ and cylindrical diameter of $24 \mathrm{~nm}$ and in presence of $8 \mathrm{~g}(0.133 \mathrm{M})$ of PEG, nanocapsules of decreased size with length of $52 \mathrm{~nm}$ and cylindrical diameter of $20 \mathrm{~nm}$ were obtained. However, in presence of excess amount of PEG (12 g, 0.2 M), the capsules got sewed up to form angular nanostructures which get interconnected to form rhombic nanostructures which get converted into nanocluster with an average length nearly equal to $101 \mathrm{~nm}$ and average width of $40 \mathrm{~nm}$ as shown in Figure 2(d). The hypothetical mechanism of capsules getting converted into nanocluster is depicted in Figure 3. Although the average particle size is different under various conditions, the nanoparticles formed have an average particle size of less than $100 \mathrm{~nm}$.

EDX analysis was used to identify the elemental composition of the samples and performed on different sites of each sample. The results showed that the samples consist of iron and oxygen, and no sign of impurity was detected and the composition exactly matches with $\mathrm{Fe}_{2} \mathrm{O}_{3}$.

3.3. Corrosion Inhibitor Coatings. The corrosion rate and corrosion resistance of iron samples coated with prepared paints involving different iron oxide powders $(0 \mathrm{M}, 0.066 \mathrm{M}$, $0.133 \mathrm{M}$, and $0.2 \mathrm{M}$ PEG) were studied. The polarization curves (Figure 4) clearly depict that it is the size and not the structure which influences the corrosion resistance behavior. If it would be structure which influences the corrosion resistance behavior, then the sample coated with $\mathrm{Fe}_{2} \mathrm{O}_{3}$ 12 PEG being a cubic structure with more close-packing should show high corrosion resistance but it is observed that the paint prepared with $\mathrm{Fe}_{2} \mathrm{O}_{3}-8$ PEG has high corrosion resistance and low corrosion rate compared to other paints; this is due to the smaller size of particles in $\mathrm{Fe}_{2} \mathrm{O}_{3}-8$ PEG. Due to the smaller size, the surface area is high, so $\mathrm{Fe}_{2} \mathrm{O}_{3}-8$ PEG exhibit good surface properties and protect the surface from corrosion (Table 2). Figure 4 also shows that the paint which is prepared with $\mathrm{Fe}_{2} \mathrm{O}_{3}-0$ PEG has low corrosion 


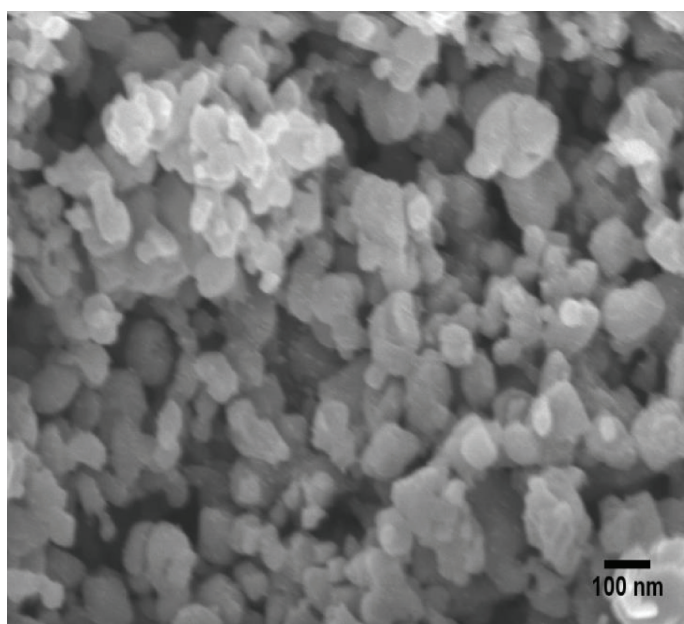

(a)

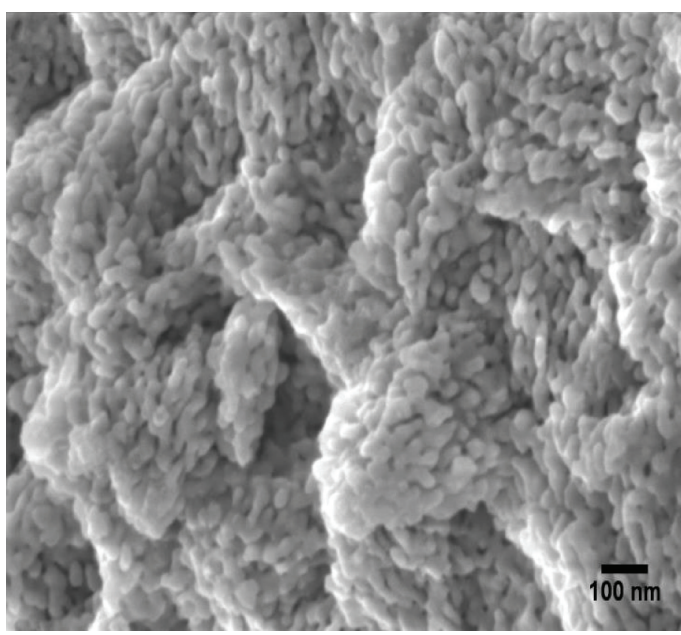

(c)

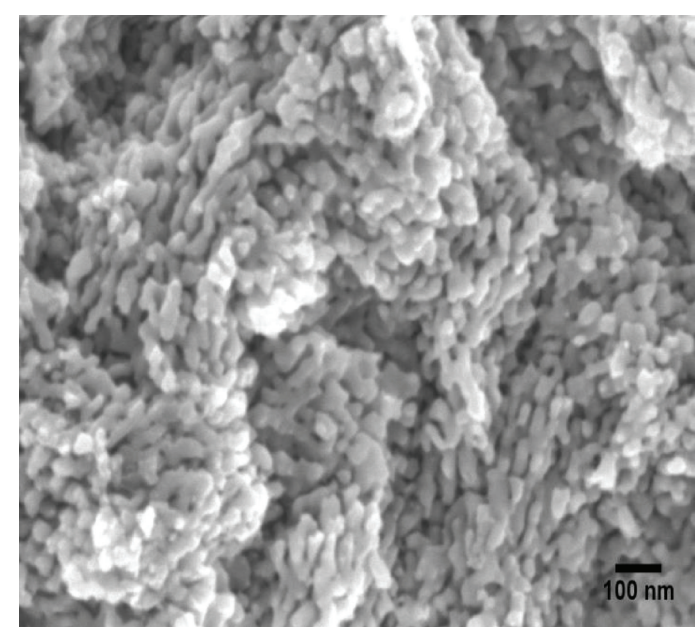

(b)

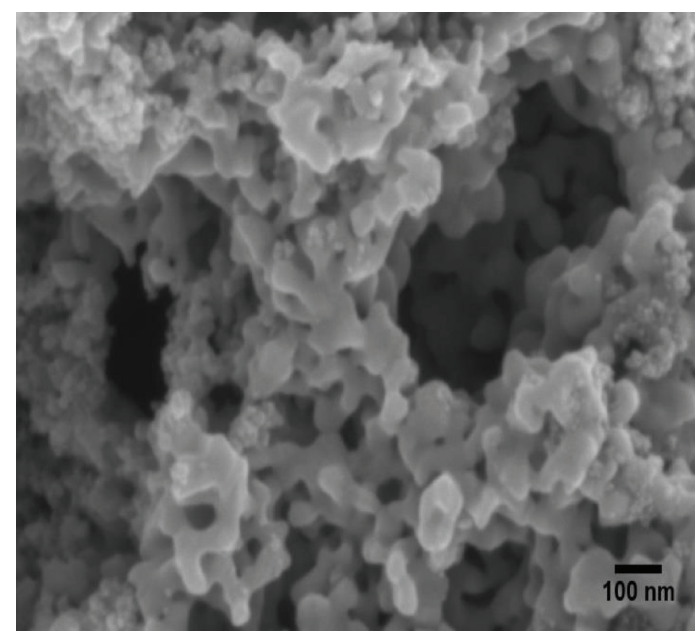

(d)

Figure 2: SEM images of (a) $\mathrm{Fe}_{2} \mathrm{O}_{3}-0$ PEG, (b) $\mathrm{Fe}_{2} \mathrm{O}_{3}-4$ PE, (c) $\mathrm{Fe}_{2} \mathrm{O}_{3}-8$ PEG, and (d) $\mathrm{Fe}_{2} \mathrm{O}_{3}-12$ PEG.

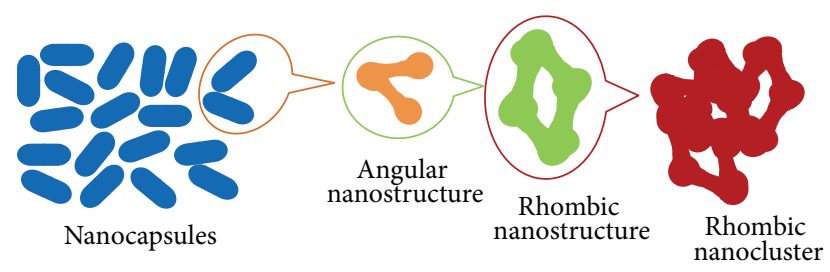

FIGURE 3: Hypothetical mechanism of aggregation of nanocapsules to nanoclusters on increasing the concentration of PEG.

resistance and high corrosion rate. Obviously, the reason is large particle size compared to other samples. From $\mathrm{Fe}_{2} \mathrm{O}_{3}$ 0 PEG paint to $\mathrm{Fe}_{2} \mathrm{O}_{3}-8$ PEG paint corrosion resistance increases. However, in the paint prepared out of $\mathrm{Fe}_{2} \mathrm{O}_{3}$ $12 \mathrm{PEG}$, corrosion resistance decreases and the reason is aggregation of nanocapsules to form nanoclustered large particles. The polarization curves (Figure 4) depict that as the size increases the corrosion resistance decreases. To explore more, the paints were prepared with microsized $\alpha-\mathrm{Fe}_{2} \mathrm{O}_{3}$
TABLE 2: Corrosion rate and corrosion resistance data from polarization curves.

\begin{tabular}{lcc}
\hline Sample code & $\begin{array}{c}\text { Corrosion rate } \\
(\mathrm{mm} / \mathrm{y})\end{array}$ & $\begin{array}{c}\text { Corrosion resistance } \\
(\mathrm{ohm})\end{array}$ \\
\hline $\mathrm{Fe}_{2} \mathrm{O}_{3}-0$ PEG & $1.24 \times 10^{-4}$ & $9.2 \times 10^{5}$ \\
$\mathrm{Fe}_{2} \mathrm{O}_{3}-4$ PEG & $1.04 \times 10^{-7}$ & $2.66 \times 10^{9}$ \\
$\mathrm{Fe}_{2} \mathrm{O}_{3}-8$ PEG & $2.59 \times 10^{-8}$ & $6.916 \times 10^{11}$ \\
$\mathrm{Fe}_{2} \mathrm{O}_{3}-12 \mathrm{PEG}$ & $9.735 \times 10^{-6}$ & $2.541 \times 10^{7}$ \\
Microsized $\mathrm{Fe}_{2} \mathrm{O}_{3}$ powder & $1.574 \times 10^{-3}$ & $4.29 \times 10^{4}$ \\
Blank sample & 0.4222 & 225.8 \\
\hline
\end{tabular}

readily available in the laboratory and tested for corrosion behavior. Interestingly, the paint prepared out of $\mathrm{Fe}_{2} \mathrm{O}_{3}$ 0 PEG which showed highest corrosion rate (Table 2) was observed to have lowest corrosion rate compared to blank uncoated sample (parent iron sample) and sample coated with paint prepared from microsized $\alpha-\mathrm{Fe}_{2} \mathrm{O}_{3}$ (Figure 5). 


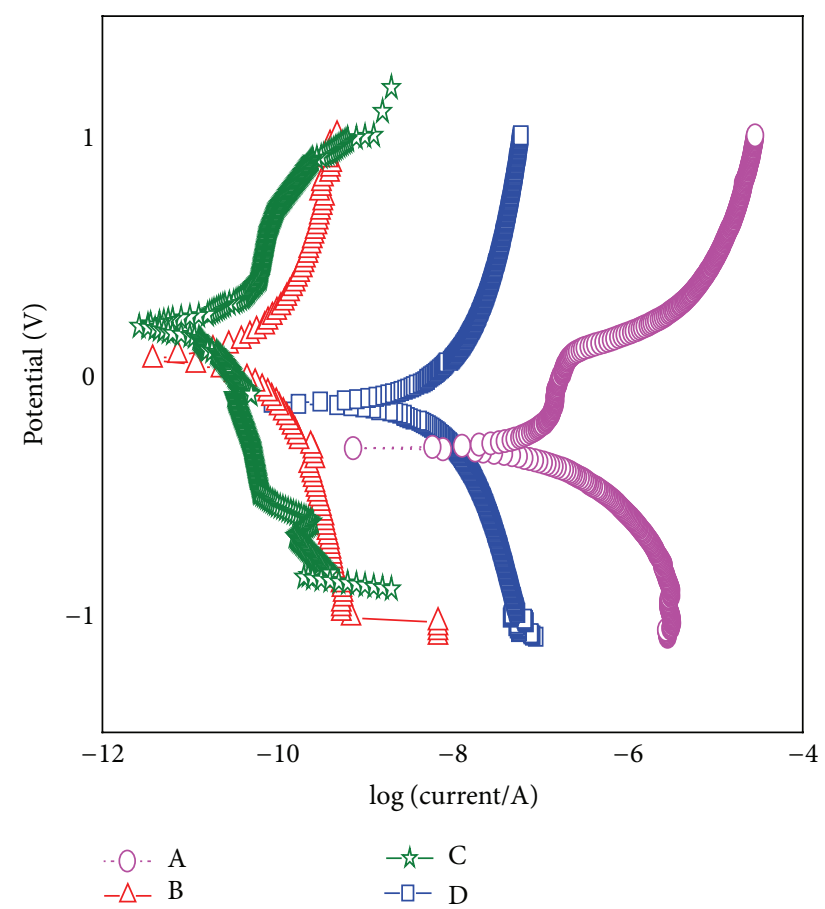

Figure 4: Polarization curves of iron samples coated with paints prepared from (A) $\mathrm{Fe}_{2} \mathrm{O}_{3}-0$ PEG, (B) $\mathrm{Fe}_{2} \mathrm{O}_{3}-4$ PEG, (C) $\mathrm{Fe}_{2} \mathrm{O}_{3}-8$ PEG, and (D) $\mathrm{Fe}_{2} \mathrm{O}_{3}-12$ PEG.

\section{Conclusion}

This paper outlines the simple method to synthesize nanocrystalline $\alpha$ - and $\gamma$-iron oxides by precipitationcalcination method. It was observed that different morphologies of iron oxide were precipitated by varying amounts of PEG, which is acting as a structure directing agent. Interestingly, powder $\mathrm{X}$-ray studies showed a phase transformation from rhombohedral hematite $\left(\alpha-\mathrm{Fe}_{2} \mathrm{O}_{3}\right)$ to cubic maghemite $\left(\gamma-\mathrm{Fe}_{2} \mathrm{O}_{3}\right)$ when the amount of PEG is increased and calcined at the same temperature $\left(500^{\circ} \mathrm{C}\right)$. Scanning electron micrographs clearly shown at low PEG content nanocapsules were formed, which aggregate to form nanocluster on addition of $12 \mathrm{~g}(0.2 \mathrm{M})$ of PEG. However, this agglomeration of nanocapsules is also responsible for phase transformation. These prepared iron oxide nanomaterials are further used in paint preparation and were found to be better protective coatings on iron samples when compared to microsized iron oxide particle coatings.

\section{Competing Interests}

The authors declare that there are no competing interests regarding the publication of this paper.

\section{Acknowledgments}

The authors wish to thank Department of MME, RGUKTBasar, for providing excellent facilities such as XRD, FESEM,

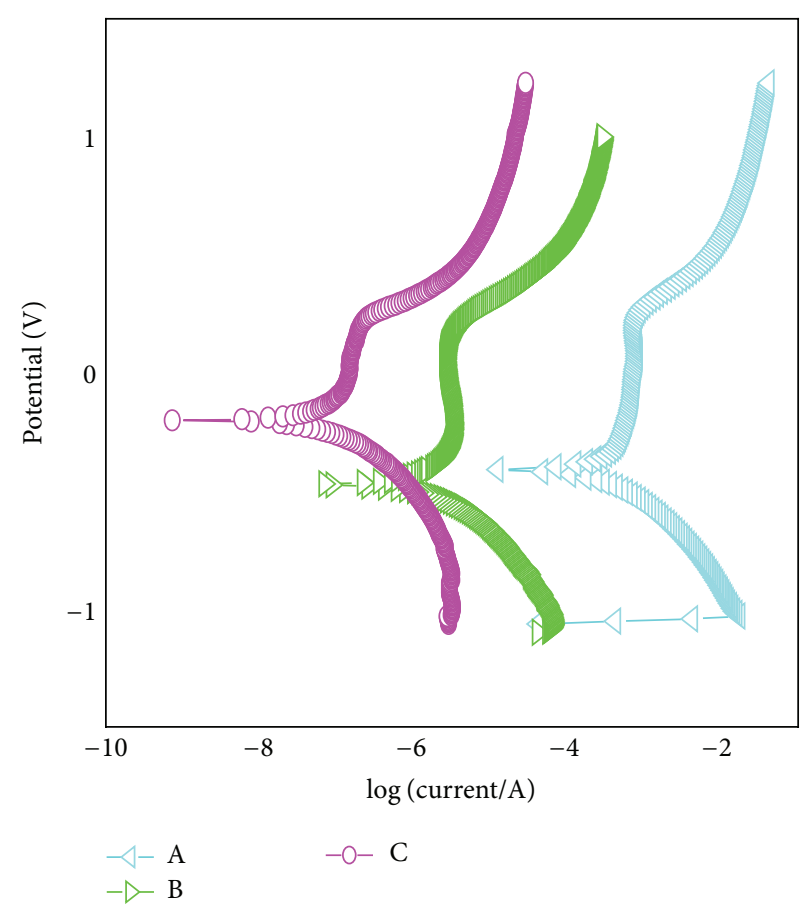

Figure 5: Polarization curves of iron samples: (A) blank sample, (B) sample coated with paint prepared from microsized $\mathrm{Fe}_{2} \mathrm{O}_{3}$ powder, and (C) sample coated with paint prepared from $\mathrm{Fe}_{2} \mathrm{O}_{3}-0$ PEG.

and potentiostat for carrying out the analysis and experimental work. They also thank Department of Chemistry for providing required chemicals for this work.

\section{References}

[1] P. Poizot, S. Laruelle, S. Grugeon, L. Dupont, and J.-M. Tarascon, "Nano-sized transition-metal oxides as negative-electrode materials for lithium-ion batteries," Nature, vol. 407, no. 6803, pp. 496-499, 2000.

[2] W. S. Seo, J. H. Shim, S. J. Oh, E. K. Lee, N. H. Hur, and J. T. Park, "Phase- and size-controlled synthesis of hexagonal and cubic $\mathrm{CoO}$ nanocrystals," Journal of the American Chemical Society, vol. 127, no. 17, pp. 6188-6189, 2005.

[3] J. B. Reitz and E. I. Solomon, "Propylene oxidation on copper oxide surfaces: electronic and geometric contributions to reactivity and selectivity," Journal of the American Chemical Society, vol. 120, no. 44, pp. 11467-11478, 1998.

[4] S. Shanmugam and A. Gedanken, "MnO octahedral nanocrystals and MnO@C core-shell composites synthesis, characterization, and electrocatalytic properties," The Journal of Physical Chemistry B, vol. 110, no. 48, pp. 24486-24491, 2006.

[5] R. H. Kodama, S. A. Makhlouf, and A. E. Berkowitz, "Finite size effects in antiferromagnetic $\mathrm{NiO}$ nanoparticles," Physical Review Letters, vol. 79, no. 7, pp. 1393-1396, 1997.

[6] R. H. Kodama, "Magnetic nanoparticles," Journal of Magnetism and Magnetic Materials, vol. 200, no. 1-3, pp. 359-372, 1999.

[7] G. Bate, "Magnetic recording materials since 1975," Journal of Magnetism and Magnetic Materials, vol. 100, no. 1-3, pp. 413$424,1991$.

[8] J. Mürbe, A. Rechtenbach, and J. Töpfer, "Synthesis and physical characterization of magnetite nanoparticles for biomedical 
applications," Materials Chemistry and Physics, vol. 110, no. 2-3, pp. 426-433, 2008.

[9] Y. Ichiyanagi, S. Moritake, S. Taira, and M. Setou, "Functional magnetic nanoparticles for medical application," Journal of Magnetism and Magnetic Materials, vol. 310, no. 2, pp. 28772879, 2007.

[10] W. Wu, X. Xiao, S. Zhang et al., "Large-scale and controlled synthesis of iron oxide magnetic short nanotubes: shape evolution, growth mechanism, and magnetic properties," Journal of Physical Chemistry C, vol. 114, no. 39, pp. 16092-16103, 2010.

[11] B. Levy, "Photochemistry of nanostructured materials for energy applications," Journal of Electroceramics, vol. 1, no. 3, pp. 239-272, 1997.

[12] T. Iwasaki, K. Kosaka, N. Mizutani et al., "Mechanochemical preparation of magnetite nanoparticles by coprecipitation," Materials Letters, vol. 62, no. 25, pp. 4155-4157, 2008.

[13] J. Xu, H. Yang, W. Fu et al., "Preparation and magnetic properties of magnetite nanoparticles by sol-gel method," Journal of Magnetism and Magnetic Materials, vol. 309, no. 2, pp. 307-311, 2007.

[14] Q. Wang, H. Yang, J. Shi, and G. Zou, “One-step synthesis of the nanometer particles of $\gamma-\mathrm{Fe}_{2} \mathrm{O}_{3}$ by wire electrical explosion method," Materials Research Bulletin, vol. 36, no. 3-4, pp. 503509, 2001.

[15] L. Cabrera, S. Gutierrez, N. Menendez, M. P. Morales, and P. Herrasti, "Magnetite nanoparticles: electrochemical synthesis and characterization," Electrochimica Acta, vol. 53, no. 8, pp. 3436-3441, 2008.

[16] C. Balasubramaniam, Y. B. Khollam, I. Banerjee et al., "DC thermal arc-plasma preparation of nanometric and stoichiometric spherical magnetite $\left(\mathrm{Fe}_{3} \mathrm{O}_{4}\right)$ powders," Materials Letters, vol. 58, no. 30, pp. 3958-3962, 2004.

[17] M. Farbod, A. Movahed, and I. Kazeminezhad, "An investigation of structural phase transformation of monosize $\gamma$ - $\mathrm{Fe}_{2} \mathrm{O}_{3}$ nanoparticles fabricated by arc discharge method," Materials Letters, vol. 89, pp. 140-142, 2012.

[18] A. Sutka, S. Lagzdina, T. Kaambre et al., "Study of the structural phase transformation of Iron oxide nanoparticles from an $\mathrm{Fe}^{2+}$ ion sourse by precipitation under various synthesis parameters and temperatures," Materials Chemistry and Physics, vol. 149150, pp. 473-479, 2015.

[19] R. M. Cornell and U. Schwertmann, The Iron Oxide: Structure and Properties, Wiley-VCH, Weinheim, Germany, 2003.

[20] F. Damien, Iron Oxide: From Nature to Applications, John Wiley \& Sons, Weinheim, Germany, 2016. 

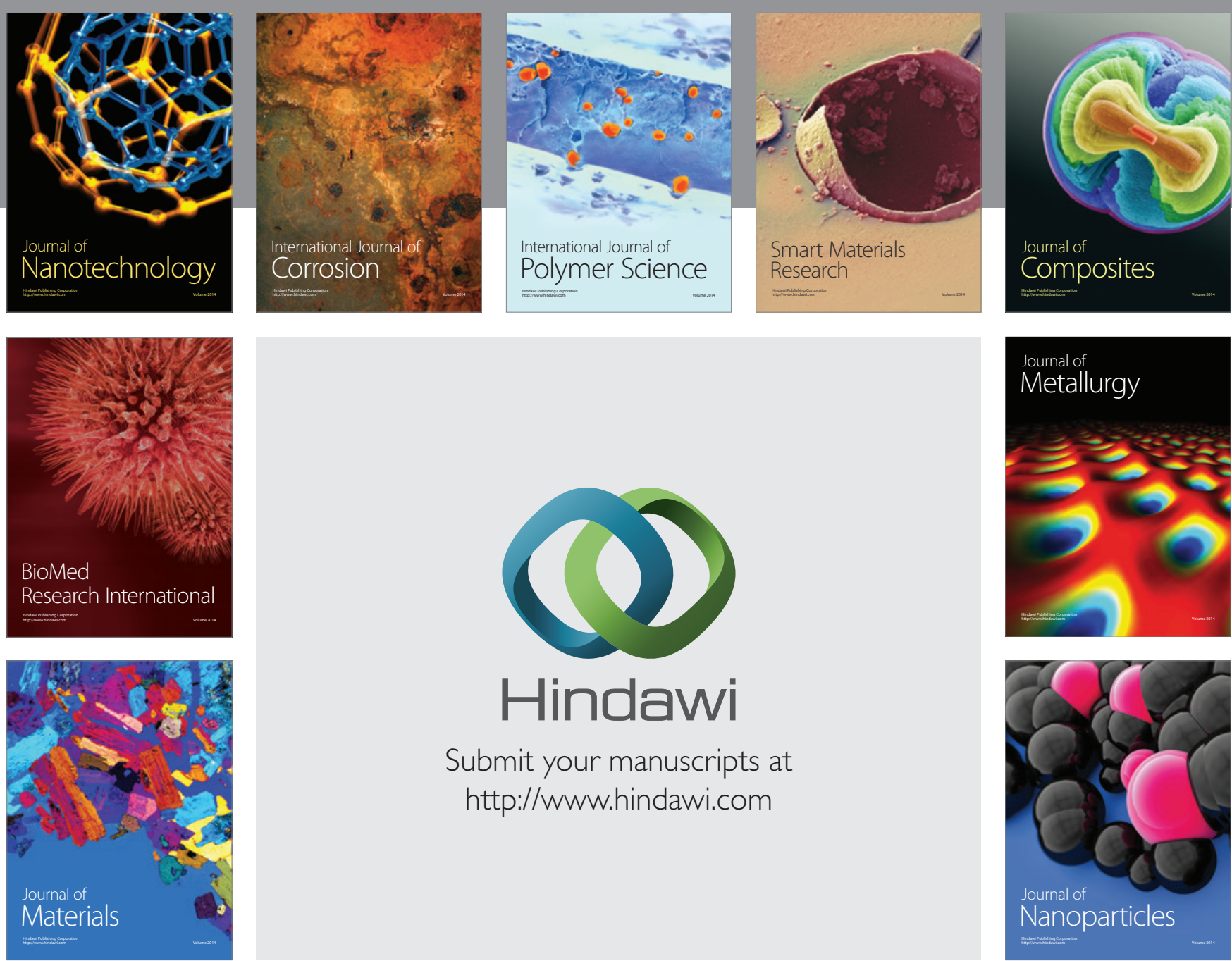

\section{Hindawi}

Submit your manuscripts at

http://www.hindawi.com

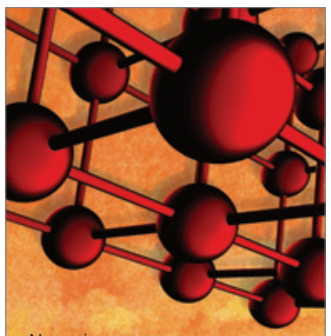

Materials Science and Engineering
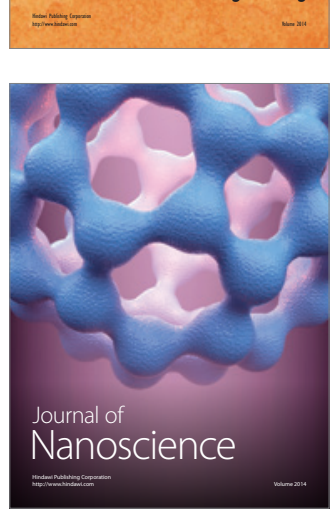
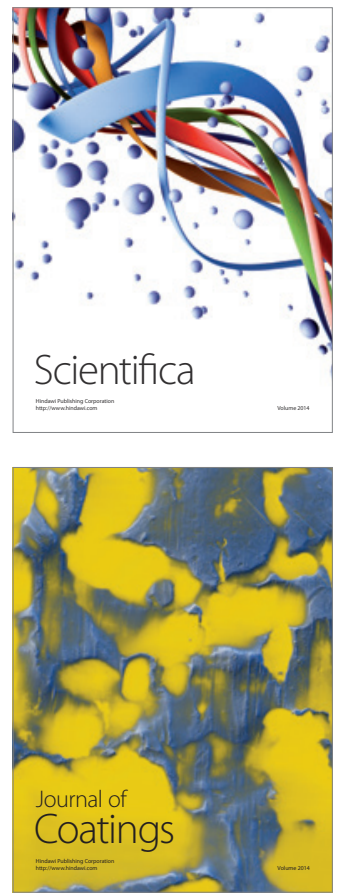
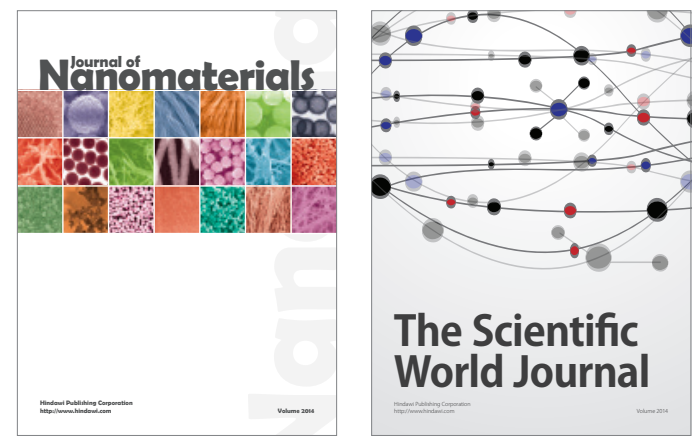

The Scientific World Journal
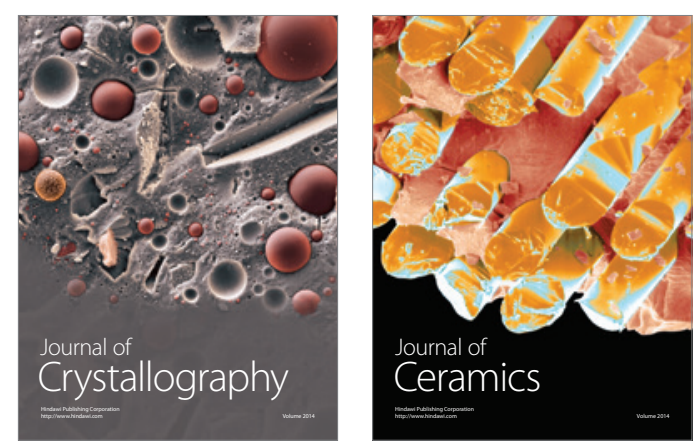
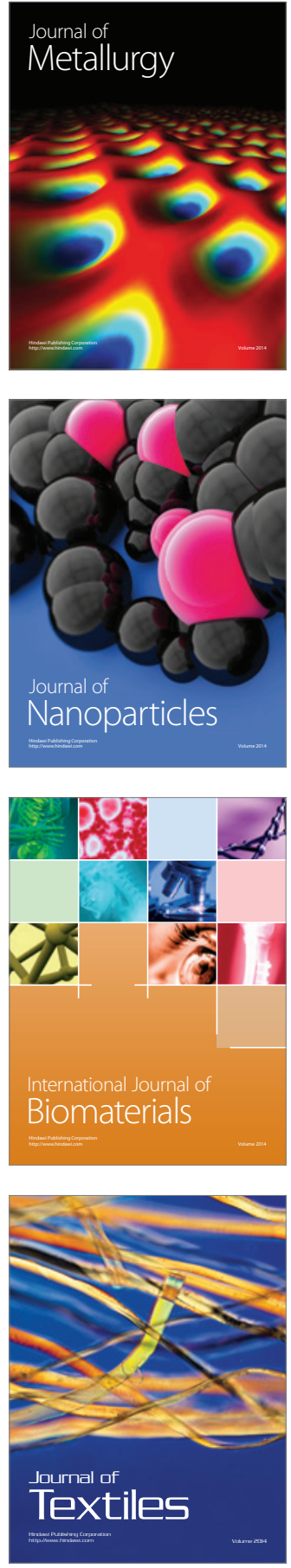